\title{
Potential of Bacillus subtilis for controlling bacterial leaf blight pathogen in rice
}

\author{
Ku Asmah, K.S. and *Sapak, Z. \\ Centre of Postgraduate Studies, Faculty of Plantation and Agrotechnology, Universiti Teknologi Mara \\ (UiTM), Jasin Campus, 77300 Merlimau, Melaka, Malaysia
}

\section{Article history:}

Received: 22 July 2020

Received in revised form: 4

December 2020

Accepted: 26 September 2020

Available Online: 27

December 2020

\section{Keywords:}

Biological control,

Bacillus subtilis,

Bacterial leaf blight,

Rice

DOI:

https://doi.org/10.26656/fr.2017.4(S5).011

\begin{abstract}
Bacterial leaf blight (BLB) of rice is an economically important disease caused by Xanthomonas oryzae pv. oryzae (Xoo) throughout the world. To control this disease, bacterial isolate of Bacillus subtilis UiTMB1 was screened for the antagonistic activity against the pathogen in vitro and in vivo studies. A bacterial assay and detached leaf technique were used to evaluate the potential of the bacterium against BLB pathogen in the laboratory. Meanwhile, the glasshouse study was conducted to further examine the aptitudes of the isolate on the disease control and growth-promoting of rice plants. The findings revealed that B. subtilis UiTMB1 is able to control the disease and enhance the growth of rice plants. Rice plants treated with $B$. subtilis UiTMB1 before being inoculated with BLB pathogen showed less severe disease symptoms with low disease severity index of 3.43 compared to rice plants without $B$. subtilis UiTMB1 with high disease severity index of 8.4. Besides controlling the disease, B. subtilis UiTMB1 was also promoting plant height, chlorophyll content, number of tillers and biomass of rice plants.
\end{abstract}

\section{Introduction}

Rice is considered a major crop and the main source of diet in Malaysia. The rice consumption pattern of the adult population in this country shows that Malaysians consume an average of two and a half plates of rice per day (Norimah, 2008). In 2014, approximately 679,239 ha were cultivated with rice and were planted twice a year (Department of Agriculture of Malaysia, 2015). According to Man and Sadiya (2009), there were approximately 116,000 out of 296,000 rice growers in Malaysia which are full-time growers who depend on rice cultivation for their livelihood. With the improvement of living conditions, efficient new environmental genial agents are crucially needed to control rice diseases. Blast, sheath blight and sheath-rot, bacterial leaf blight, tungro virus and bakanae are considered as major diseases of rice (Gnanamanickam, 2009). Bacterial leaf blight (BLB) of rice caused by Xanthomonas oryzae pv. oryzae (Xoo) is one of the oldest recognized diseases and it was first noticed by the farmers of Japan in 1884 (Takami, 1962). The disease is always causing great losses of rice production as it is widely spread across Malaysia including Perlis, Kedah, Pulau Pinang, Selangor, Melaka and Kelantan (Islam et al., 2007). A previous study by Saad (2000) stated that cultivation of susceptible rice variety MR 84 attacked by
BLB in 1988 to 1994 had caused a huge loss estimated about RM 50 million during those years. The disease infestation affects the reduction of grain yield up to $50 \%$ at various levels depending on the technique of rice planting, degree of rice cultivar susceptibility, stage of growing crops, and the conduciveness of environment which the disease can occur and spread among the rice plants (Gnanamanickam et al., 1999). Serious damages caused by BLB on rice have demanded the development of reliable strategies to manage the disease. Nowadays, the repeated and over applications of antibiotics and chemical pesticide compounds appear to be an affliction to the environment, human safety and also the emergence of pesticide resistance. Shifting to biological control agents as an alternative control method for the disease is gaining much attention among researchers to explore the potential of beneficial microbes against the BLB pathogen. For instance, Gangwar and Sinha (2010) and Dipankar et al. (2017) reported that Trichoderma harzianum and Pseudomonas fluorescens have potential as bio-control agents for BLB disease in India. Meanwhile, Sumera et al. (2016) found that the application of Pseudomonas spp. Rh323 is not only able to suppress BLB disease, but it also promotes plant growth of Basmati rice by producing secondary metabolites such as enzymes and hormones. The abilities 
of Bacillus spp. to inhibit the growth of BLB and enhance plant growth have been widely reported, for example, a study conducted in China revealed that Bacillus amyloliquefaciens has the ability to reduce BLB infestation and significantly increase plant fresh weight from $50.03 \%$ to $73.11 \%$ and dry weight from $64.11 \%$ to $86.65 \%$ in the treated rice plants (El-shakh et al., 2015). Meanwhile He et al., (2019) applied B. subtilis strain BJ1 for controlling blast disease of rice caused by fungal pathogen Magnaporthe oryzae in China. Besides rice, Bacillus spp. has been reported as a biological control agent for many other crop diseases such as B. Subtilis for anthracnose disease of red pepper (Lee et al., 2020) and chilli (Ashwini and Srividya, 2014), tomato diseases (Cucu et al., 2020), controlling aflatoxigenic Aspergillus parasiticus (Siahmoshteh et al., 2018), maize disease (Douriet-Gámez et al., 2017) and many other diseases. Although a few studies have investigated the bio-control efficacy of B. subtilis on rice such as Yang et al., (2009) for controlling blast disease, there is no research involving $B$. subtilis against BLB of rice under Malaysia climatic condition. Therefore, the main objective of this present study was to evaluate the potential of $B$. subtilis (UiTMB1) isolated from asymptomatic rice leaves as a biological control agent for controlling BLB and growthpromoting capabilities to rice plants in the glasshouse. This will provide the potential strain for developing the effective bio-control product of managing this disease.

\section{Materials and methods}

\subsection{Pathogen and Bacillus subtilis}

The pathogen $X$. oryzae pv. oryzae was obtained from a ready stock at the laboratory of Plant Pathology, Faculty of Plantation and Agrotechnology, Universiti Teknologi MARA (UiTM). Meanwhile, B. subtilis UiTMB1 was isolated from asymptomatic rice leaves collected from Jitra, Kedah, Malaysia. The isolate was identified and confirmed as B. subtilis by using a Biolog System ${ }^{\circledR}$ and based on cultural and morphological characteristics. The bacterial isolate coded as B. subtilis UiTMB1 can be described as an aerobic, sporeproducing, Gram-positive, rod-shaped bacterium (0.7$0.8 \times 2.0-3.0 \mu \mathrm{m})$. The catalase reaction, gelatin liquefaction, starch hydrolysis, casein hydrolysis, sugar fermentation, and Voges-Proskauer tests were all positive, while the oxidase reaction and indole test were negative. These data indicated that strain UiTMB1 was a member of the genus Bacillus.

\subsection{Bioassay of B. subtilis UiTMB1 against the pathogen}

Bacterial activity assay and detached leaf technique were used to evaluate the efficacy of $B$. subtilis UiTMB1 against the BLB pathogen in vitro and in vivo experiments. A method of bacterial activity assay proposed by Hastuti et al. (2012) was used to observe and measure the formation of the clear zone between the pathogen and B. subtilis UiTMB1. In this bacterial assay, $1 \mathrm{~mL}$ of BLB pathogen suspension $\left(10^{8} \mathrm{CFU} / \mathrm{mL}\right)$ was spread uniformly on Nutrient agar in the Petri plate and incubated at $28 \pm 2^{\circ} \mathrm{C}$ for $24 \mathrm{hrs}$ prior to inoculation with B. subtilis UiTMB1. A fresh culture of $24 \mathrm{hr}$-old $B$. subtilis UiTMB1 on Nutrient agar was taken out as a disc with a diameter of $5 \mathrm{~mm}$ by a cork borer and then placed on the BLB pathogen. The plate was then allowed to incubate for another seven days before observing and measuring the formation of a clear zone surrounding the disc. Nutrient agar disc without pathogen was also placed on BLB pathogen to serve as controls. This plate treatment was carried out in five replicates. Meanwhile, the detached leaf technique was conducted using healthy rice leaf segment as suggested by Akhtar et al. (2008). Rice leaf segments (variety MR263) obtained from rice plants grown in the glasshouse for 60 days were in this experiment. The leaf segments with a size of $5 \mathrm{~cm}$ in length were surface sterilized with $10 \%$ of sodium hypochlorite solution for $30 \mathrm{~s}$ to eliminate unwanted microbes and then rinsed with sterile distilled water twice. The leaf segments were dipped in the BLB suspension $\left(10^{8} \mathrm{CFU} / \mathrm{mL}\right)$ and then placed on moist sterilized filter paper in the Petri plate. Then, $1 \mathrm{~mL}$ of $B$. subtilis UiTMB1 was dispensed uniformly on the inoculated leaf segments and kept in the incubator at $30 \pm 2^{\circ} \mathrm{C}$ for 14 days. The leaf segments inoculated with pathogen alone served as a positive control.

\subsection{Preparation of rice seedlings and experimental design}

Susceptible rice variety MR263 seeds were soaked in sterile water overnight in order to enhance germination (Hastuti et al., 2012). The seeds were then grown on a moist sterilized filter paper in the Petri plates and maintained in a growth chamber at $30 \pm 2^{\circ} \mathrm{C}$ and $100 \%$ relative humidity $(\mathrm{RH})$ for five days. Thus, the germinated seeds were then transferred into plastic growth chambers with a diameter of $28 \mathrm{~cm}$ containing clay loam soils. For each plastic growth chamber, five germinated seeds were transplanted and grown in a month prior to the experiment. This experiment consists of five treatments as shown in Table 1. Each treatment consisted of 10 replicates and all replicates were assigned in completely randomized design in the glasshouse.

2.4 Preparation and inoculation of B. subtilis UiTMB1 inoculum on rice seedlings

Inoculum of $B$. subtilis UiTMB1 was prepared by 
transferring 10 loops of $24 \mathrm{hr}$-old culture into $100 \mathrm{~mL}$ nutrient broth and grown for $48 \mathrm{hrs}$ in the incubator shaker at the setting temperature of $28 \pm 2{ }^{\circ} \mathrm{C}$ and shaken at $150 \mathrm{rpm}$. The broth culture was then diluted in sterile distilled water and adjusted the colony forming unit (CFU) to $10^{8}-10^{9} \mathrm{CFU} / \mathrm{mL}$ according to a method by Krishanti et al. (2015). Suspension of BLB pathogen was also prepared following the same procedure and adjusted to $10^{8}-10^{9} \mathrm{CFU} / \mathrm{mL}$. Both suspensions of pathogen and B. subtilis UiTMB1 were applied to rice seedlings by spraying using different sets of hand sprayer with $50 \mathrm{~mL}$ for each growth chamber. Rice plants in the treatments of T1C, T2P and T3C were inoculated with BLB pathogen by cutting off the leaf tips and dipping for 2 mins in the pathogen suspension to provide a high chance for the disease infection then followed by spraying the pathogen suspension to the plants. After seven days, the preinoculated plants with a BLB pathogen in the treatment T1C were sprayed with $B$. subtilis UiTMB1 suspension and this treatment served as a curative treatment to assess the ability of the agent to combat the established pathogen on the rice plants. In contrast, rice plants in the treatment of $\mathrm{T} 2 \mathrm{P}$ were served as a preventive treatment to evaluate the ability of $B$. subtilis UiTMB1 to prevent the plants from the pathogen attacks. Meanwhile, rice plants inoculated with pathogen alone in the treatments of $\mathrm{T} 3 \mathrm{C}$ were used as a negative control and rice plants inoculated with $B$. subtilis UiTMB1 alone (T4C) were used as a positive control (Table 1).

Table 1. Five treatments used to evaluate the efficacy of $B$. subtilis (UiTMB1) to inhibit BLB pathogen and enhance the growth performance of rice plants

\begin{tabular}{ll}
\hline \multicolumn{1}{c}{ Treatment } & \multicolumn{1}{c}{ Description } \\
\hline 1. Curative (T1C) & $\begin{array}{l}\text { Inoculation with BLB pathogen for } \\
\text { seven days then followed by B. subtilis } \\
\text { Inoculation with B. subtilis seven days } \\
\text { then followed by BLB pathogen }\end{array}$ \\
$\begin{array}{ll}\text { 2. Preventive (T2P) } \\
\text { 3. Negative Control } \\
\text { (T3C) }\end{array}$ & $\begin{array}{l}\text { Inoculation with BLB pathogen alone } \\
\text { 4. Positive control } \\
\text { (T4C) }\end{array}$ \\
$\begin{array}{l}\text { 5. Healthy Control } \\
\text { (T5C) }\end{array}$ & Without any inoculation \\
\hline
\end{tabular}

\subsection{Disease severity and plant growth assessments}

Biological control aptitudes of $B$. subtilis UiTMB1 against $X$. oryzae pv. oryzae on rice plants were assessed based on disease severity index (DSI) that was previously developed by IRRI (1996) according to a formula of DSI as below:

$$
D S I=\frac{n(1)+n(3)+n(5)+n(7)+n(9)}{t n}
$$

Where: $\mathrm{n}(1), \mathrm{n}(3), \mathrm{n}(5), \mathrm{n}(7)$ and $\mathrm{n}(9)=$ Number of leaves showing severity score of $1,3,5,7$ and $9 . t n=$ Total number of leaves scored.
Disease severity was recorded as a percentage of the leaf tissue area infected out of a total leaf area examined. The following scale as shown in Table 2 (Chaudhary, 1996) was used for scoring of BLB severity on rice plants. The growth performance of the treated rice plants with $B$. subtilis UiTMB1 was assessed weekly by collecting the data of plant height, the number of tillers, length of roots, chlorophyll content, plant dry weight (biomass) and grain yield. The collected data were then analysed statistically by ANOVA and Least Significant Difference (LSD) at $\mathrm{P} \leq 0.05$.

Table 2. Disease severity scale for evaluation of bacterial leaf blight of rice in the field

\begin{tabular}{cc}
\hline Disease Rating & Percentage of infected leaf area by BLB \\
\hline 0 & 0 \\
1 & $1>1-10 \%$ \\
2 & $3>11-30 \%$ \\
3 & $5>31-50 \%$ \\
4 & $7>51-75 \%$ \\
5 & $9>76-100 \%$ \\
\hline
\end{tabular}

2.6 Colonization of B. subtilis (UiTMB1) in Rice leaf Tissues

Colonization of inoculated $B$. subtilis UiTMB1 in rice leaf tissues was assessed based on a method of Mattos et al. (2008). At the final stage of the glasshouse experiment, destructive sampling of rice leaves from the treatments of $\mathrm{TC} 1, \mathrm{~T} 2 \mathrm{P}$ and $\mathrm{T} 4 \mathrm{C}$ were conducted to evaluate the colonization of $B$. subtilis UiTMB1 in the leaf tissues. The rice leaves were collected from four pots of rice plants for each treatment and brought to the laboratory. The rice leaves were washed under running tap water and cut into small segments of $1 \mathrm{~cm}$ in length before its surface was sterilized with $1 \%$ of sodium hypochlorite for $10 \mathrm{mins}$ and $70 \%$ ethanol for $1 \mathrm{~min}$, then followed by rinsing with sterile distilled water twice. The rice leaf segments were weighed to about $1 \mathrm{~g}$ and then crushed in $5 \mathrm{~mL}$ of sterile saline with mortar and pestle. The suspensions were then refined using filter papers and diluted into 10 -fold serial dilutions before $100 \mu \mathrm{L}$ was spread onto NA plates. The NA plates were incubated at $28 \pm 2{ }^{\circ} \mathrm{C}$ for $2-4$ days and three replicates of the NA plates were used for each treatment. Bacterial colonization in the rice leaf tissues was counted and expressed as colony-forming unit (CFU) per fresh weight plant tissues (g).

\section{Results and discussion}

\subsection{Bioassay of B. subtilis UiTMB1 against the pathogen}

Results of bacterial activity assay and detached leaf technique proved that $B$. subtilis UiTMB1 was able to inhibit the growth of BLB pathogen. A $42 \mathrm{~mm}$ of clear inhibition zone formed surrounding the disc of $B$. subtilis 
UiTMB1 indicated that the biological agent inhibited the growth of pathogen which was not observed on the control disc. This finding was further supported by the results of a detached leaf experiment that revealed $B$. subtilis UiTMB1 is able to combat the attack of BLB pathogen on rice leaf segments as shown in Figure 1. The leaf segments inoculated with BLB pathogen and $B$. subtilis UiTMB1 showed fewer symptoms of BLB, however, the disease symptoms have appeared on the leaf segments inoculated with BLB pathogen alone. The ability to inhibit the growth pathogen could be associated with secretion of antimicrobial substances such as antibiotics, enzyme, toxin and other proteins. According to Hussain et al. (2017), bacitracin A and polymyxin B which are peptides families of antibiotic separated from crude lyophilized extracts of B. subtilis have strong inhibition ability against some pathogens. There is a high possibility the clear inhibition zone produced by $B$. subtilis UiTMB1 was due to the antibiotic action. (a)

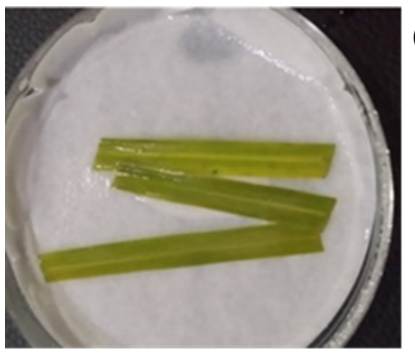

(b)

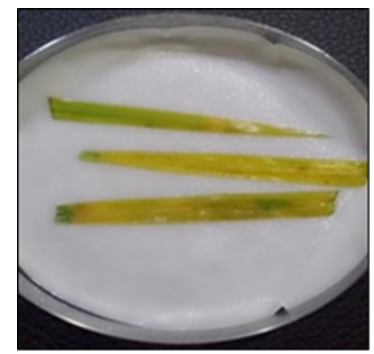

Figure 1. Inoculated rice leaf segments with BLB pathogen and $B$. subtilis UiTMB1. (a) The rice leaf segments inoculated with BLB pathogen and B. subtilis UiTMB1 showed less symptoms of the disease as compared to (b) the control treatment with BLB pathogen alone.

\subsection{Disease severity index and plant growth performance}

The effectiveness of $B$. subtilis UiTMB1 against BLB pathogen within the first three weeks of observation indicated that the lowest disease severity was recorded for the T2P treatment with DSI value of $2.94 \%$ and then followed by the treatment of T1C with $4.10 \%$ (Table 3 ). In contrast, the highest DSI was observed in the treatment of $\mathrm{T} 3 \mathrm{C}$ (negative control) with 5.58\%. Furthermore, the findings showed that the rice plants treated with $B$. subtilis UiTMB1 prior to inoculation with the BLB pathogen (T2P- preventive) recorded only $3.43 \%$ DSI at six weeks of observation as compared to the rice plants treated with the BLB first, then $B$. subtilis UiTMB1 (4.50\% DSI) (T1C- curative). These results suggested that $B$. subtilis UiTMB1 has potential to protect rice plants from a severe infection of the BLB pathogen (Figure 2). The isolate of B. subtilis UiTMB1 also has the ability to prevent and cure the plants of BLB disease. In contrast, rice plants in the treatment of negative control (T3C) with BLB pathogen alone recorded the highest DSI after six weeks of observation
Table 3. Disease severity index recorded for the treatments of rice plants inoculated with $B$. subtilis UiTMB1 and BLB pathogen for six weeks

\begin{tabular}{cccc}
\hline \multirow{2}{*}{$\begin{array}{c}\text { Observation } \\
\text { week }\end{array}$} & \multicolumn{3}{c}{ Disease severity index (DSI) } \\
\cline { 2 - 4 } & $\begin{array}{c}\text { T1C } \\
\text { (Curative) }\end{array}$ & $\begin{array}{c}\text { T2P } \\
\text { (Preventive) }\end{array}$ & $\begin{array}{c}\text { T3C (Negative } \\
\text { Control) }\end{array}$ \\
\hline 1 & $0.57 \pm 0.31^{\mathrm{a}}$ & 0 & $1.39 \pm 0.09^{\mathrm{b}}$ \\
2 & $1.90 \pm 0.21^{\mathrm{b}}$ & $0.59 \pm 0.04^{\mathrm{a}}$ & $2.43 \pm 0.04^{\mathrm{c}}$ \\
3 & $4.10 \pm 0.11^{\mathrm{b}}$ & $2.94 \pm 0.19^{\mathrm{a}}$ & $5.58 \pm 0.14^{\mathrm{c}}$ \\
4 & $4.10 \pm 0.11^{\mathrm{a}}$ & $4.13 \pm 0.19^{\mathrm{a}}$ & $6.48 \pm 0.09^{\mathrm{b}}$ \\
5 & $5.11 \pm 0.22^{\mathrm{a}}$ & $4.97 \pm 0.12^{\mathrm{a}}$ & $6.66 \pm 0.11^{\mathrm{b}}$ \\
6 & $4.50 \pm 0.38^{\mathrm{a}}$ & $3.43 \pm 0.16^{\mathrm{a}}$ & $8.36 \pm 0.12^{\mathrm{b}}$ \\
LSD(P $\leq 0.05)$ & 0.003 & 0.001 & 0.132 \\
\hline
\end{tabular}

Values are expressed as mean \pm standard error (SE). Values with the different superscripts within the row are significantly different according to the t-test at $\mathrm{P}<0.05$.

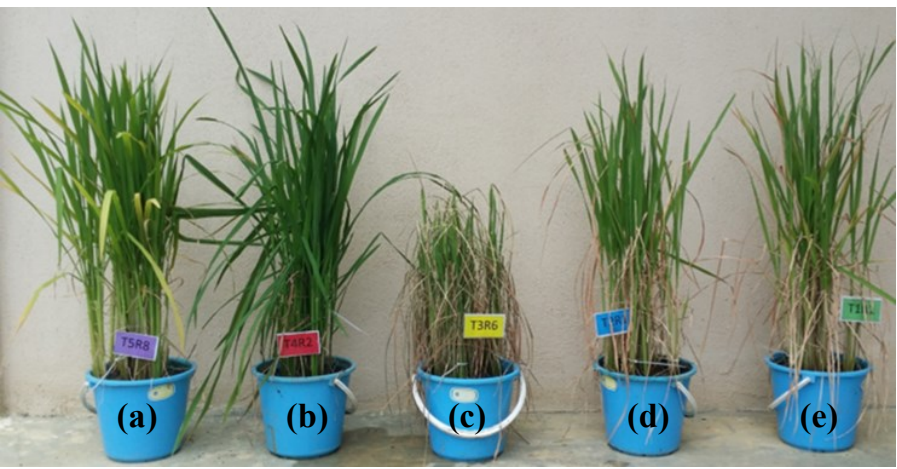

Figure 2. Rice plants treated with and without BLB pathogen and B. subtilis UiTMB1 displayed the different levels of DSI. (a) Plant without any inoculations (T5C), (b) plant inoculated with B. subtilis UiTM alone, (c) pathogen alone, (d) preventive and (e) curative treatment.

on the disease symptom development. The disease progress with time displayed that the BLB severity recorded in the treatment $\mathrm{T} 3 \mathrm{C}$ (negative control) was constantly increasing consecutively. A similar trend for the BLB severity was recorded in the treatments of T1C and T2P, however, the progress was slow and the signs of disease recovery on rice leaves can be spotted on week six and this recovery can be related to the decreasing the DSI value (Table 3). Rice plants applied with $B$. subtilis UiTMB1 (T4C) were observed to be growing healthier than the rest as shown in Figure 2. The growth performance of rice plants due to $B$. subtilis UiTMB1 was evaluated based on plant height, chlorophyll content, number of tiller and length of roots as shown in Table 4. The findings showed that rice plants with $B$. subtilis UiTMB1 (T4C) to be growing taller than rice plants without the bacterial inoculum in the control treatment (T5C). A similar trend was observed for the chlorophyll content, the number of tillers and root length between rice plants with and without $B$. subtilis UiTMB1. This result proved that the biological control agent $B$. subtilis UiTMB1 is able to promote plant growth. Potential of $B$. subtilis as plant growth promoters has been reported by many researchers 
Table 4. Effect of application B. subtilis UiTMB1 on growth performance of rice plants

\begin{tabular}{lcccc}
\hline \multicolumn{1}{c}{ Treatment } & Plant Height (cm) & Chlorophyll Content & No. of Tiller & Length of Root (cm) \\
\hline Curative (T1C) & $93.50 \pm 1.80^{\mathrm{a}}$ & $33.79 \pm 0.63^{\mathrm{c}}$ & $11 \pm 0.58^{\mathrm{d}}$ & $43.33 \pm 3.38^{\mathrm{a}}$ \\
Preventive (T2P) & $92.33 \pm 0.88^{\mathrm{a}}$ & $33.91 \pm 1.68^{\mathrm{c}}$ & $15 \pm 0.67^{\mathrm{c}}$ & $40.00 \pm 1.00^{\mathrm{a}}$ \\
Negative Control (T3C) & - & - & - & - \\
Positive control (T4C) & $93.67 \pm 0.88^{\mathrm{a}}$ & $42.78 \pm 0.47^{\mathrm{a}}$ & $24 \pm 0.33^{\mathrm{a}}$ & $51.00 \pm 2.08^{\mathrm{a}}$ \\
Healthy control (T5C) & $88.83 \pm 0.44^{\mathrm{b}}$ & $38.46 \pm 0.74^{\mathrm{b}}$ & $20 \pm 0.67^{\mathrm{b}}$ & $40.66 \pm 5.20^{\mathrm{a}}$ \\
\hline
\end{tabular}

Values are expressed as mean \pm standard error (SE). Values with the different superscripts within the row are significantly different according to the t-test at $\mathrm{P}<0.05$.

Table 5. Effect of application B. subtilis UiTMB1 towards biomass of rice plants

\begin{tabular}{lcccc}
\hline \multicolumn{1}{c}{ Treatment } & Leaves $(\mathrm{g})$ & Stem $(\mathrm{g})$ & Roots $(\mathrm{g})$ & Panicles $(\mathrm{g})$ \\
\hline Curative (T1C) & $4.24 \pm 0.49^{\mathrm{b}}$ & $9.57 \pm 1.21^{\mathrm{b}}$ & $9.63 \pm 1.09^{\mathrm{b}}$ & $14.74 \pm 1.64^{\mathrm{b}}$ \\
Preventive (T2P) & $3.98 \pm 0.37^{\mathrm{b}}$ & $9.34 \pm 0.57^{\mathrm{b}}$ & $6.97 \pm 0.67^{\mathrm{b}}$ & $13.11 \pm 1.73^{\mathrm{b}}$ \\
Negative Control (T3C) & - & - & - & - \\
Positive control (T4C) & $12.62 \pm 0.28^{\mathrm{a}}$ & $13.21 \pm 1.08^{\mathrm{a}}$ & $23.67 \pm 2.92^{\mathrm{a}}$ & $22.15 \pm 0.32^{\mathrm{a}}$ \\
Healthy control (T5C) & $4.98 \pm 0.10^{\mathrm{b}}$ & $11.40 \pm 0.90^{\mathrm{ab}}$ & $7.69 \pm 0.67^{\mathrm{b}}$ & $15.15 \pm 2.27^{\mathrm{b}}$ \\
\hline
\end{tabular}

Values are expressed as mean \pm standard error (SE). Values with the different superscripts within the row are significantly different according to the t-test at $\mathrm{P}<0.05$.

such as Rekha et al. (2020) in rice, Lee et al. (2020) in wheat and Jamily et al. (2019) in barley and many other studies. Previous studies by Chen et al. (2007) and Harman (2011) discovered that Bacillus species could enhance the biosynthesis of plant growth-promoting hormones such as Gibberellic acid (GA3) and Indole-3acetic acid (IAA). Meanwhile, the similar trend observed for the chlorophyll content, the results showed that the highest chlorophyll content recorded by SPAD in the treatment of T4C and compared to other treatments. The lowest chlorophyll content recorded in both treatments of T1C and T2P could be explained by chlorosis symptoms due to BLB disease. The highest number of tillers (24 tillers) and the lengthiest of roots $(51 \mathrm{~cm})$ were also recorded in the treatment $\mathrm{T} 4 \mathrm{C}$. This finding proved that B. subtilis UiTMB1 is promoting the plant growth of rice. This finding could be related with the findings of Rekha et al. (2020) mentioned that B. subtilis RR4 AF1 able to promote rice growth by enhancing the production of primary metabolite malic acid and the secondary metabolite salicylic acid in roots. Furthermore, the results of the biomass of leaves, stem, roots and panicles showed that there was a significant difference among the treatments at $\mathrm{P} \leq 0.05$ (Table 5). Biomass of rice leaves in the treatment $\mathrm{T} 4 \mathrm{C}$ showed the highest weight with $12.62 \mathrm{~g}$ and then followed by treatment T5C (4.98 g), but the lowest weight was observed in the treatment T2P (3.98 g) (Table 5). A similar result was obtained for the biomass of stems, roots and panicles where the highest value was recorded in the treatment $\mathrm{T} 4 \mathrm{C}$ and the lowest value in the treatment T2P.

\subsection{Colonization of B. subtilis UITMB1 in rice leaf tissues}

Leaf tissues of rice colonized by bacterial $B$. subtilis UiTMB1 were examined and the findings proved that $B$. subtilis UiTMB1 in the treatments $\mathrm{T} 1 \mathrm{C}$ and $\mathrm{T} 2 \mathrm{P}$ has an ability to colonize the plant tissues and at the same time suppress the BLB pathogen. This is reflected by the high population density of $B$. subtilis obtained in the treatment T4C with $2.7 \times 10^{9} \mathrm{CFU} \mathrm{g}^{-1}$ and then followed by $\mathrm{T} 1 \mathrm{C}$ and T2P as shown in Table 6 . This result indicated that the biological control agent is able to maintain its population within leaf tissues.

Table 2. Disease severity scale for evaluation of bacterial leaf blight of rice in the field

\begin{tabular}{lc}
\hline Treatment & Population Density $\left(\times 10^{9} \mathrm{CFU} / \mathrm{g}\right)$ \\
\hline Curative (T1C) & $2.1 \pm 0.67^{\mathrm{a}}$ \\
Preventive (T2P) & $2.3 \pm 0.51^{\mathrm{a}}$ \\
Positive control (T4C) & $2.7 \pm 0.77^{\mathrm{a}}$ \\
\hline
\end{tabular}

Values are expressed as mean \pm standard error (SE). Values with the different superscripts within the column are significantly different according to the t-test at $\mathrm{P}<0.05$.

\section{Conclusion}

Our data indicate that B. subtilis UiTMB1 has great potential as a bio-control agent and also as plant growthpromoting bacterium. However, this study would be more interesting with the mechanisms used by the isolate to inhibit the pathogen of BLB which is not covered by the study. The production of antimicrobial compounds either enzymes, toxins or other proteins will need to be identified in the future. Great potential is shown by the isolate and could be explored further to improve the efficacy of the bacterium under the real conditions in the rice fields by developing a reliable and stable formulation of a bio-control agent using recent technology.

\section{Conflict of interest}

The authors declare no conflict of interest. 


\section{Acknowledgements}

The authors gratefully acknowledge the Faculty of Plantation and Agrotechnology staff for technical help and support.

\section{References}

Akhtar, M.A., Rafi, A. and Hameed, A. (2008). Comparison of methods of inoculation of Xanthomonas oryzae pv. oryzae in rice cultivars. Pakistan Journal of Botany, 40(5), 2171-2175.

Ashwini, N. and Srividya, S. (2014). Potentiality of Bacillus subtilis as biocontrol agent for management of anthracnose disease of chilli caused by Colletotrichum gloeosporioides OGC1. 3 Biotech, 4, 127-136. https://doi.org/10.1007/s13205-013-0134-4

Chaudhary, R.C. (1996). Internationalization of elite germplasm for farmers: Collaborative mechanisms to enhance evaluation of rice genetic resources. Characterization and Evaluation. The Fourth Ministry of Agriculture, Forestry and Fisheries, Japan (MAFF), International Workshop on Genetic Resources. Japan.

Chen, X.H., Koumoutsi, A., Scholz, R., Eisenreich, A., Schneider, K., Heinemeyer, I., Morgenstern, B., Voss, B., Hess, W.R., Reva, O. and Junge, H. (2007). Comparative analysis of the complete genome sequence of the plant growth-promoting bacterium Bacillus amyloliquefaciens FZB42. Nature Biotechnology, 25, 1007-1014. https:// doi.org/10.1038/nbt1325

Cucu, M.A., Gilardi, G., Pugliese, M., Gullino, M.L. and Garibaldi, A. (2020). An assessment of the modulation of the population dynamics of pathogenic Fusarium oxysporum f. sp. lycopersici in the tomato rhizosphere by means of the application of Bacillus subtilis QST 713, Trichoderma sp. TW2 and two composts. Biological Control, 142, 104158. https://doi.org/10.1016/j.biocontrol.2019.104158

Dipankar, M., Rini, P. and Mohanty, A.K. (2017). Management of bacterial leaf blight of rice in an integrated way. Journal of Mycopathological Research, 54(4), 539-541. https:// www.cabdirect.org/cabdirect/abstract/20173083326

Douriet-Gámez, N.R., Maldonado-Mendoza, I.E., IbarraLaclette, E., Blom, J. and Calderón-Vázquez, C.L. (2018). Genomic analysis of Bacillus sp. Strain B25, a biocontrol agent of maize pathogen Fusarium verticillioides. Current Microbiology, 75, 247-255. https://doi.org/10.1007/s00284-017-1372-1

El-shakh, A.S., Kakar, K.U., Wang, X., Almoneafy, A.A., Ojaghian, M.R., Li, B., Anjum, S.I. and Xie, G.L. (2015). Controlling bacterial leaf blight of rice and enhancing the plant growth with endophytic and rhizobacterial Bacillus strains. Toxicological and Environmental Chemistry, 97, 766-785. https:// doi.org/10.1080/02772248.2015.1066176

Gangwar, G.P. and Sinha, A.P. (2010). Comparative antagonistic potential of Trichoderma spp. against Xanthomonas oryzae pv. oryzae. Annals of Plant Protection Sciences, 18(2), 458-463. https:// www.cabdirect.org/cabdirect/abstract/20103366678

Gnanamanickam, S.S. (2009). Biological control of rice diseases - volume 8. Dordrecht, the Netherlands: Springer Science and Business Media. https:// doi.org/10.1007/978-90-481-2465-7

Gnanamanickam, S.S., Priyadarisini, V.B., Narayanan, N.N., Vasudevan, P. and Kavitha, S. (1999). An overview of bacterial blight disease of rice and strategies for its management. Current Science, 77 (11), 1435-1444. https://www.jstor.org/ stable/24105230

Harman, G.E. (2011). Multifunctional fungal plant symbionts: new tools to enhance plant growth and productivity. New Phytologist, 189(3), 647-649. https://doi.org/10.1111/j.1469-8137.2010.03614.x

Hastuti, R.D., Lestari, Y., Suwanto, A. and Saraswati, R. (2012). Endophytic Streptomyces spp. as biocontrol agents of rice bacterial leaf blight pathogen (Xanthomonas oryzae pv. oryzae). HAYATI Journal of Biosciences, 19(4), 155-162. https:// doi.org/10.4308/hjb.19.4.155

He, Y., Zhu, M., Huang, J., Hsiang, T. and Zheng, L. (2019). Biocontrol potential of a Bacillus subtilis strain BJ-1 against the rice blast fungus Magnaporthe oryzae. Canadian Journal of Plant Pathology, 41(1), 47-59. https:// doi.org/10.1080/07060661.2018.1564792

Hussain, M.Y., Ali-Nizam, A.A. and Abou-Isba, S.M. (2017). Antibacterial Activities (Bacitracin A and Polymyxin B) of Lyophilized Extracts from Indigenous Bacillus subtilis Against Staphylococcus aureus. Jordan Journal of Biological Sciences, 10 (3), 205-212.

IRRI. (1996). Standard Evaluation System for Rice. Genetic Resource Centre. Manila, Philippines

Islam, Z., Nik, N.M.N., Man, A., Hussain, Y., Abdullah, S., Heong, K.L., Bell, M. and Sivapragasam, A. (2007). Influence of mechanization on rice pests in Peninsular Malaysia and their management. Outlooks on Pest Management, 18(2), 87-91. https:// doi.org/10.1564/18apr11

Jamily, A.S., Koyama, Y., Win, T.A., Toyota, K., Chikamatsu, S., Shirai, T., Uesugi, T., Murakami, H., Ishida, T. and Yasuhara, T. (2019). Effects of 
inoculation with a commercial microbial inoculant Bacillus subtilis C-3102 mixture on rice and barley growth and its possible mechanism in the plant growth stimulatory effect. Journal of Plant Protection Research, 59(2), 193-205.

Krishanti, N.P.R.A., Wahyudi, A.T. and Nawangsih, A.A. (2015). Non-pathogenic phyllosphere bacteria producing bioactive compounds as biological control of Xanthomonas oryzae pv oryzae. International Journal of Pharma and Bio Sciences, 6(1), 801-810.

Lee, S., Trịnh, C.S., Lee, W.J., Jeong, C.Y., Truong, H.A., Chung, N., Kang, C.S. and Lee, H. (2020). Bacillus subtilis strain L1 promotes nitrate reductase activity in Arabidopsis and elicits enhanced growth performance in Arabidopsis, lettuce, and wheat. Journal of Plant Research, 133, 231-244. https:// doi.org/10.1007/s10265-019-01160-4

Lee, Y.Y., Lee, Y., Kim, Y.S., Kim, H.S. and Jeon, Y. (2020). Control of Red Pepper Anthracnose Using Bacillus subtilis YGB36, a Plant Growth Promoting Rhizobacterium. Research in Plant Disease, 26(1), 8 -18. https://doi.org/10.5423/RPD.2020.26.1.8

Man, N. and Sadiya, S.I. (2009). Off-farm employment participation among paddy farmers. In in the MUDA Agricultural Development Authority and Kemasin Semerak Granary areas of Malaysia. Asia-Pacific Development, 16(2), 141-153. https:// doi.org/10.18356/cb961558-en

Norimah, J.A., Safiah, M., Jamal, K., Haslinda, S., Zuhaida, H., Rohida, S., Fatimah, S., Norazlin, S., Poh, B.K., Kandiah, M. and Zalilah, M.S. (2008). Food Consumption Patterns: Findings from the Malaysian Adult Nutrition Survey (MANS). Malaysian Journal of Nutrition, 14(1), 25-39. https:// pubmed.ncbi.nlm.nih.gov/22691762/

Rekha, K., Ramasamy, M. and Usha, B. (2020). Root exudation of organic acids as affected by plant growth-promoting rhizobacteria Bacillus subtilis RR4 in rice. Journal of Crop Improvement, 34(4), 116. https://doi.org/10.1080/15427528.2020.1746719

Saad, A., Habibuddin, H., Alias, I., Othman, O., Azlan, S. and Zulkifli, R. (2000). Resistance status of released varieties after MR 84 against bacterial blight and the incidence on the disease in Muda irrigation scheme presented at the Proceedings of the Conference of Plant Resources Management. Kuching, Sarawak, Malaysia.

Siahmoshteh, F., Hamidi-Esfahani, Z., Spadaro, D., Shams-Ghahfarokhi, M. and Razzaghi-Abyaneh, M. (2018). Unraveling the mode of antifungal action of Bacillus subtilis and Bacillus amyloliquefaciens as potential biocontrol agents against aflatoxigenic Aspergillus parasiticus. Food Control, 89, 300-307. https://doi.org/10.1016/j.foodcont.2017.11.010

Tagami, Y. (1962). Historical review of the researchers on bacterial leaf blight of rice caused by Xanthomonas oryzae (Uyeda et Ishiyama) Dowson; Special report. Plant Disease and Insect Pests Forecasting Service, 10, 112. https://ci.nii.ac.jp/ naid/10021061708/

Yang, D., Wang, B., Wang, J., Chen, Y. and Zhou, M. (2009). Activity and efficacy of Bacillus subtilis strain NJ-18 against rice sheath blight and Sclerotinia stem rot of rape. Biological Control, 51 (1), 61-65. https://doi.org/10.1016/ j.biocontrol.2009.05.021 